\title{
Shift towards the dominance of boreal species in the Arctic: inter-annual and spatial zooplankton variability in the West Spitsbergen Current
}

\author{
Agata Weydmann ${ }^{1, *}$, Jacob Carstensen ${ }^{2}$, Ilona Goszczko ${ }^{1}$, Katarzyna Dmoch ${ }^{1}$, \\ Anna Olszewska ${ }^{1}$, Slawomir Kwasniewski ${ }^{1}$
}

${ }^{1}$ Institute of Oceanology, Polish Academy of Sciences, Powstancow Warszawy St. 55, 81-712 Sopot, Poland

${ }^{2}$ Department of Bioscience, Aarhus University, 4000 Roskilde, Denmark

\begin{abstract}
We studied summer mesozooplankton composition between 2001 and 2009, in the epipelagic zone of the West Spitsbergen Current (WSC) and adjacent areas, which constitute a transition zone between warmer Atlantic and cold Arctic waters. According to hydrography and species composition, this region could be divided into 4 main areas: western and eastern branches of the WSC, the Greenland Sea together with Fram Strait, and the shelf areas of Spitsbergen and the Barents Sea. The most abundant species was Oithona similis and the most important, in terms of biomass, was Calanus finmarchicus; both species were found at all stations. The novel spatial analysis method of principal coordinates of neighbour matrices (PCNM) and the following variation partitioning were applied to disentangle the contributions of environmental variables and spatial differences in explaining mesozooplankton community variation. In spite of the large geographic area covered, environmental factors used in redundancy analysis (RDA) explained $30.6 \%$ of zooplankton variability, while the spatial distribution of sampling stations was responsible for $27.2 \%$, and $12.5 \%$ was a common share of both predictors, coming from their correlations. We observed a smooth change from dominance of ubiquitous and boreo-Arctic taxa such as $O$. similis and Triconia sp. in the beginning of the study period towards stronger dominance of boreal taxa such as C. finmarchicus, which was the most abundant species in 2009.
\end{abstract}

KEY WORDS: North Atlantic · Mesozooplankton · Calanus finmarchicus · Redundancy analysis . Variation partitioning $\cdot$ Principal coordinates of neighbour matrices $\cdot$ Long-term data series

Resale or republication not permitted without written consent of the publisher

\section{INTRODUCTION}

The West Spitsbergen Current (WSC), which is the continuation of the Norwegian Atlantic Current, transports Atlantic waters (AW) and associated biota through the Norwegian and Greenland Seas, and thus influences both physical and biological properties of the Arctic Ocean (Piechura \& Walczowski 2009). The WSC is a transition zone between the considerably warmer Atlantic and the cold Arctic domains, and as such it is a suitable place to study effects of climate change in Arctic and sub-Arctic marine ecosystems. Warming of the
WSC waters has been observed recently with maximum high AW temperature and salinity recorded in summer 2006. In the following 2 years, both variables decreased rapidly, but AW temperature and salinity were high again in summer 2009 (Piechura \& Walczowski 2009, Walczowski et al. 2012). On the basis of these observations, Spielhagen et al. (2011) suggested that AW temperatures observed west of Spitsbergen in the beginning of the 21st century may have been the warmest of the past 2000 yr.

Knowing that temperature has increased significantly in the Arctic over the last 3 to 4 decades (IPCC 
[Intergovernmental Panel on Climate Change] 2007, Stroeve et al. 2007), it has been hypothesised that effects of temperature increases could be assessed from biological long-term monitoring data in the Arctic region (Hughes 2000, Hays et al. 2005, Kirby \& Beaugrand 2009, Carstensen et al. 2012). However, most of the existing biological data sets from the Arctic have a much shorter time scale of monitoring and are without a consistent spatial factor (i.e. sampling is not repeated at the same locations through time). This complicates the analyses of such data and diminishes the possibility to extract time series that are not biased by changes in spatial sampling pattern (Beare \& McKenzie 1999, deYoung et al. 2004).

Nonetheless, Carstensen et al. (2012) investigated the effects of environmental conditions on the biomass of Calanus spp. in the Nordic Seas in 2001 to 2009 and reported significant relationships with temperature, including a critical threshold around $6^{\circ} \mathrm{C}$, above which the presence and biomass of $C$. glacialis decreased. Mumm et al. (1998), in their $5 \mathrm{yr}$ study of transpolar distribution of mesozooplankton, found out that mesozooplankton in the WSC was evenly distributed throughout the upper $500 \mathrm{~m}$, with C. finmarchicus as the prevailing species. Recently, Kwasniewski et al. (2012) studied inter-annual changes (2001 to 2008) in zooplankton composition in relation to hydrography on the West Spitsbergen Shelf as well as their connection to the North Atlantic Oscillation (NAO), and identified time lags of 4 to $7 \mathrm{yr}$ between changes in NAO and the biological response. However, zooplankton from the WSC has not been thoroughly investigated in the whole area of its influence, because most data sets are confined spatially or temporally, and consequently, long-term studies of a broader geographic area are especially sparse.

The goal of this study was to describe the interannual and spatial variability of the mesozooplankton community in the Atlantic-Arctic transition zone, using an almost decadal long and spatially comprehensive monitoring data set from the West Spitsbergen Current. We also wanted to distinguish the effects of 2 sets of explanatory variables, environmental factors and spatial distribution of sampling stations, on the variation of zooplankton taxonomic composition and its demographic structure. We applied a novel statistical method following variation partitioning, principal coordinates of neighbour matrices (PCNM), which provides a powerful tool for analysing the spatial variation in species composition and has mainly been applied in terrestrial studies (Legendre et al. 2009, Peres-Neto \& Legendre 2010).

\section{MATERIALS AND METHODS}

\section{Sample collection and analysis}

Zooplankton was sampled annually at the end of June and beginning of July, within a $3 \mathrm{wk}$ time window from 2001 until 2009, usually during or slightly after the spring bloom, from RV 'Oceania' (Table 1). The spatial extent of this data set covers multiple sampling stations in the area from $73^{\circ} 30^{\prime}$ to $78^{\circ} 50^{\prime} \mathrm{N}$ and from $3^{\circ}$ to $19^{\circ} \mathrm{E}$, including eastern and western branches of the WSC, shelf areas of Spitsbergen and the Barents Sea, and the Greenland Sea with Fram Strait (Fig. 1). Twenty stations (A to U), which were sampled for at least $5 \mathrm{yr}$ during the study period, were selected for further analysis (Fig. 1). This resulted in 138 sample collections in total. Due to the ship's drift and sea conditions, the exact geographic position of a sampling station may differ slightly between years.

Mesozooplankton was collected with a WP2 net, equipped with $180 \mu \mathrm{m}$ filtering gauze, in a vertically stratified manner within the epipelagic zone of the sea (Table 1). Water temperature and salinity were measured prior to zooplankton sampling using the Sea-Bird Electronics CTD (SBE 911plus) system with temperature and conductivity sensors, in order to investigate the origin of the different water masses.

Zooplankton samples were preserved in a $4 \%$ solution of buffered formaldehyde in seawater immediately after sampling. Most of the copepods were identified to species or genus level, and for larger copepods that were collected representatively (Calanus finmarchicus, C. glacialis, C. hyperboreus, Metridia longa and Pseudocalanus spp.), the copepodite developmental stages were also identified. To discriminate between specific Calanus species, the prosome length was measured following the procedure described by Weydmann \& Kwasniewski (2008). Copepod biomasses were calculated from the abundance data and individual dry mass (DM) values, according to BłachowiakSamołyk et al. (2008). To study the contribution of species originating from different zoographical ranges, all holoplankton taxa identified to species level were assigned into 4 categories according to their centres of distribution: ubiquitous, Arctic, boreal and boreo-Arctic (Jaschnov 1970, Lindley 1977, Corkett \& McLaren 1979, Park 1994, Razouls et al. 2005-2012, Kosobokova et al. 2011; and the World Register of Marine Species [WoRMS], www. marinespecies.org). 
Table 1. Sampling details: stations with their geographic position, mean water depth, median sampling depth of the sampling period, dates (given as dd.mm.) and years of sampling at a certain station

\begin{tabular}{|c|c|c|c|c|c|c|}
\hline Stn & $\begin{array}{l}\text { Latitude } \\
{ }^{\circ} \mathrm{N}\end{array}$ & $\begin{array}{l}\text { Longitude } \\
{ }^{\circ} \mathrm{E}\end{array}$ & $\begin{array}{c}\text { Mean water } \\
\text { depth (m) }\end{array}$ & $\begin{array}{l}\text { Median sampling } \\
\text { depth }(\mathrm{m})\end{array}$ & $\begin{array}{l}\text { Sampling } \\
\text { date }\end{array}$ & $\begin{array}{l}\text { Sampling } \\
\text { years }\end{array}$ \\
\hline $\mathrm{A}$ & $73^{\circ} 30$ & $09^{\circ} 50$ & 2240 & 95 & $23-26.06$. & $2001,2002,2006-2009$ \\
\hline B & $73^{\circ} 30$ & $13^{\circ} 05$ & 1596 & 60 & $22-27.06$ & 2001-2005, 2007, 2009 \\
\hline $\mathrm{C}$ & $73^{\circ} 30$ & $15^{\circ} 00$ & 659 & 55 & $22-27.06$ & 2001-2007, 2009 \\
\hline $\mathrm{D}$ & $73^{\circ} 30$ & $19^{\circ} 20$ & 470 & 200 & $21-27.06$ & 2005-2009 \\
\hline $\mathrm{E}$ & $75^{\circ} 00$ & $05^{\circ} 00$ & 2747 & 60 & $25.06 .-02.07$ & 2005-2009 \\
\hline $\mathrm{F}$ & $75^{\circ} 00$ & $10^{\circ} 25$ & 2532 & 100 & $27.06 .-04.07$ & $2001,2004-2006,2009$ \\
\hline $\mathrm{G}$ & $75^{\circ} 00$ & $13^{\circ} 00$ & 1972 & 60 & $27.06 .-04.07$ & $2001-2003,2005,2009$ \\
\hline $\mathrm{H}$ & $75^{\circ} 00$ & $15^{\circ} 00$ & 1113 & 60 & $28.06 .-05.07$ & $2001-2003,2005-2009$ \\
\hline I & $76^{\circ} 00$ & $13^{\circ} 00$ & 1511 & 72.5 & 29.06.-03.07. & 2001-2005, 2007-2009 \\
\hline $\mathrm{J}$ & $76^{\circ} 00$ & $15^{\circ} 00$ & 334 & 80 & 29.06.-04.07. & 2001-2009 \\
\hline $\mathrm{K}$ & $76^{\circ} 08$ & $17^{\circ} 00$ & 300 & 200 & 28.06.-07.07. & 2001-2009 \\
\hline $\mathrm{L}$ & $76^{\circ} 30$ & $04^{\circ} 00$ & 2575 & 60 & $02-11.07$ & $2004,2006-2009$ \\
\hline M & $76^{\circ} 30$ & $09^{\circ} 00$ & 2269 & 200 & $03-13.07$ & 2001-2009 \\
\hline $\mathrm{N}$ & $76^{\circ} 30$ & $13^{\circ} 00$ & 1728 & 80 & $03-07.07$. & 2001-2005, 2008, 2009 \\
\hline $\mathrm{O}$ & $76^{\circ} 30$ & $15^{\circ} 00$ & 172 & 120 & $04-14.07$. & 2001-2007, 2009 \\
\hline $\mathrm{P}$ & $77^{\circ} 14$ & $03^{\circ} 00$ & 2767 & 200 & $03-10.07$ & $2003-2009$ \\
\hline $\mathrm{R}$ & $77^{\circ} 00$ & $06^{\circ} 00$ & 2540 & 62.5 & $03-12.07$ & $2001,2003-2009$ \\
\hline $\mathrm{S}$ & $77^{\circ} 24$ & $08^{\circ} 00$ & 2181 & 72.5 & $02-07.07$ & 2004-2009 \\
\hline $\mathrm{T}$ & $78^{\circ} 50$ & $05^{\circ} 00$ & 2191 & 70 & $10-17.07$ & $2001,2002,2004,2006-2008$ \\
\hline $\mathrm{U}$ & $78^{\circ} 50$ & $09^{\circ} 15$ & 203 & 60 & $10-15.07$. & $2001,2002,2004-2006,2008,2009$ \\
\hline
\end{tabular}

\section{Data analysis}

Data analysis focused on the epipelagic zone by integrating the surface and subsurface sampling layers (the median depth of these layers was $60 \mathrm{~m}$ ), which represented mostly surface AW. Species abundance data (individuals [ind.] $\left.\mathrm{m}^{-2}\right)$ were $\log (x+1)$ transformed prior to all following analyses to allow identification of the possible influence of numerically less important taxa. To reveal similarities between years and sampling locations for both hydrographical conditions and zooplankton community composition, significance tests for differences between separated groups of samples were performed using the 1-way analysis of similarities (ANOSIM) permutation tests in PRIMER 6.0 (Plymouth Marine Laboratory).

To study the relationships between the mesozooplankton community and both environmental variables and spatial distribution of sampling sites, constrained ordination techniques were applied in CANOCO 4.5 (Leps \& Smilauer 2003). Redundancy analysis (RDA) was performed using environmental variables as predictors (water depth at a station, actual sampling depth, water temperature, salinity, sea ice concentrations and monthly chlorophyll a concentrations from June and July), ranked according to their quantitative importance by forward selection. Chlorophyll a concentrations were taken from SeaWiFS 9 km (2001 to 2002) and MODIS-Aqua

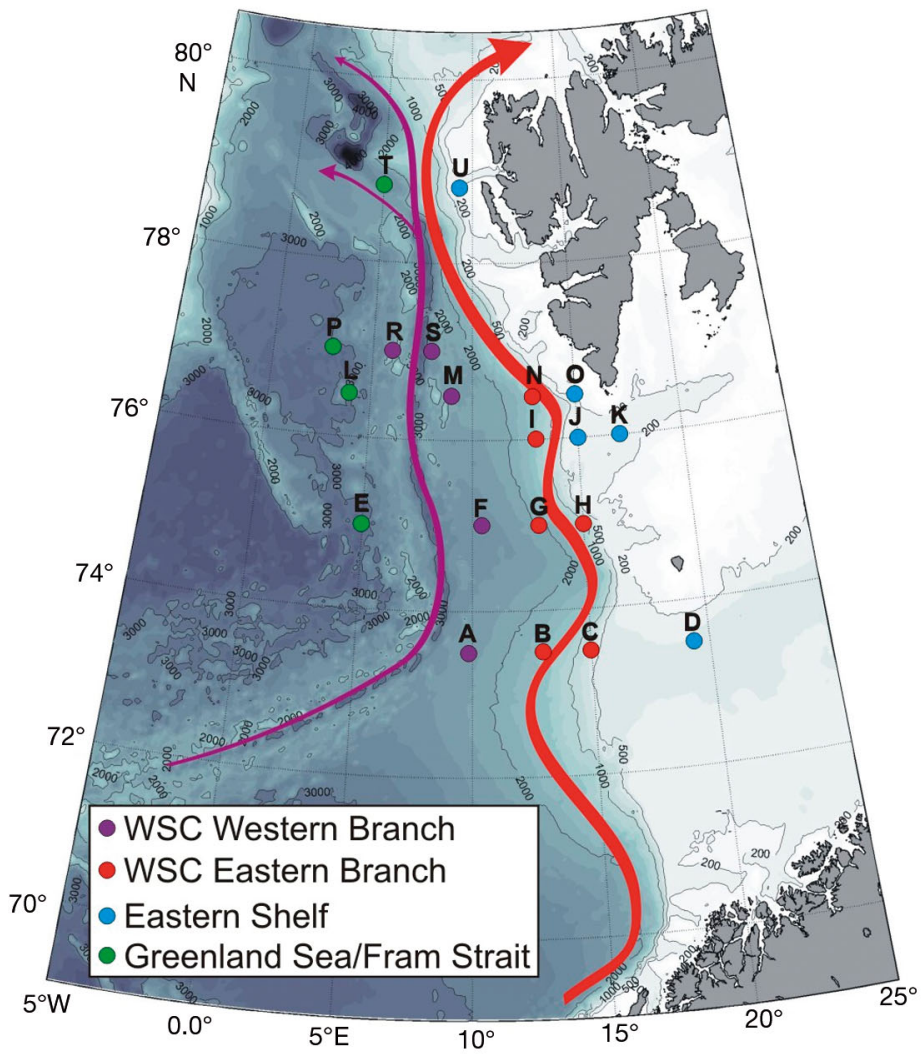

Fig. 1. Location of zooplankton sampling stations in the West Spitsbergen Current (WSC) used in the present study, partitioned into 4 distinct areas influenced by different water masses. The general flow of the WSC eastern and western branches is illustrated with arrows 
$4 \mathrm{~km}$ (2003 to 2009) data from an online Giovanni application (disc.sci.gsfc.nasa.gov/giovanni/; Acker \& Leptoukh 2007). To illustrate the geographic distribution of species, the parallels of latitudes based on the generalised linear model (GLM) were added to the RDA ordination plot.

To detect and quantify spatial patterns in the mesozooplankton community over such a large sampling area as the WSC and adjacent waters, the novel method of PCNM was employed. This method can be applied to any set of sites providing a good coverage of the geographic sampling area in order to quantify spatial structuring of ecological data, which originates either from the physical forcing of environmental variables or from community processes (Borcard \& Legendre 2002). In the first step, a truncated Euclidian distance matrix among the sampling sites was constructed on the basis of their geographic coordinates. In the second step, principal coordinates of the distance matrix were computed by principal coordinate analysis in order to represent the spatial information in a form compatible with canonical ordination (in this study it was RDA), and as a result, 82 PCNM eigenfunctions with positive eigenvalues were generated. Then the principal coordinates, derived from these positive eigenvalues, were used as explanatory variables in RDA (for details of the method see Borcard \& Legendre 2002). Additionally, forward selection was applied to the PCNM results to determine whether the WSC mesozooplankton spatial structure was mostly broad-, middle- or finescaled (Legendre et al. 2009).

Variation partitioning for RDA was applied to compare the mesozooplankton variability connected with the influence of environmental factors with effects of their spatial distribution, using 1 set of response variables (mesozooplankton community composition) and 2 sets of predictors: environmental variables (water and sampling depth, temperature, salinity, sea ice and chlorophyll a concentrations) and significant spatial descriptors derived from PCNM (Legendre et al. 2009, Peres-Neto \& Legendre 2010).

Similarity percentages (SIMPER) analysis was used to decompose average Bray-Curtis dissimilarities between different years in terms of species composition, and to determine the contribution of each species to the within-groups similarity. In addition to the above calculations, the second stage analysis (2STAGE) based on weighted Spearman's correlations was applied to taxa abundances at the sampling stations (inner factor) over the years (outer factor) in PRIMER 6.0, and illustrated by a non-metric multi- dimensional scaling (MDS) plot in order to reveal differences and similarities in zooplankton community composition between sampling years (Clarke et al. 2006).

\section{RESULTS}

\section{Hydrographical and ice conditions}

Stations were partitioned into 4 different types (Fig. 1) according to their geographic position as well as to hydrographical conditions characterised by environmental variables (temperature, salinity, sea ice concentration and water depth): western (stations $A, F, M, R, S$ ) and eastern (B, C, G, H, I, N) branches of the WSC, eastern shelf area $(D, J, K, O, U)$ and stations influenced by water masses from the Greenland Sea and Fram Strait (E, L, P, T) (1-way ANOSIM, global test $\mathrm{p}=0.001$, global $\mathrm{R}=0.488$ ), with all the pairwise tests being significant.

Since environmental variables, like zooplankton samples, were integrated for the surface and subsurface layers (median extension of the integrated layer from $60 \mathrm{~m}$ to the surface), they mostly captured characteristics of the surface water, which only partially characterises the entire AW flow into the WSC. However, temperature and salinity of the surface AW displayed fluctuations from year to year, similar to those of the AW core below (Walczowski et al. 2012), with maximum values of temperature and salinity in 2002 , 2006, 2009 and lower values in 2001, 2004 and 2008 (Fig. 2).

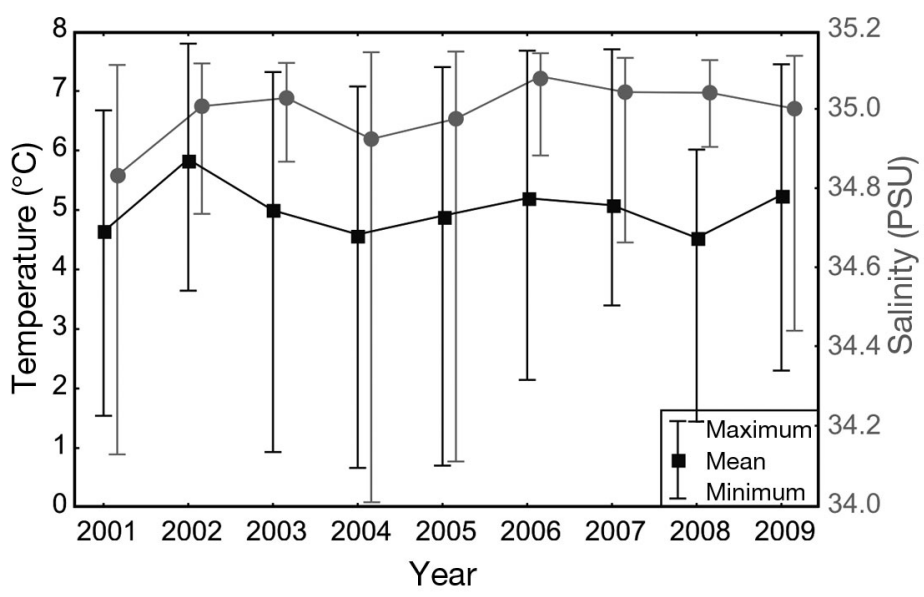

Fig. 2. Means of temperature and salinity of sampling layers (median extension of the integrated layer from $60 \mathrm{~m}$ to the surface) at stations 


\section{Species composition}

The mesozooplankton community in the study area included over 100 taxa originating from 3 biogeographic domains: boreal, boreo-Arctic and Arctic, as well as ubiquitous species (Table 2). However, both in terms of abundance and biomass, the community was dominated by a few species. Oithona similis was generally the most abundant, with typically around 30000 ind. $\mathrm{m}^{-2}$. However, in terms of biomass, Calanus finmarchicus was the most important, with values around $1200 \mathrm{mg} \mathrm{DM} \mathrm{m}^{-2}$, an order of magnitude higher than other species (Table 2). In general, C. finmarchicus, Pseudocalanus spp., O. similis and copepoda nauplii (mainly Calanus spp.) were the most frequently occurring taxa, found in every single sample across the entire study area.

Comparison of the mesozooplankton composition among stations revealed that the community could be grouped similarly to the types based on hydrography: western and eastern branches of WSC, eastern shelf area and the Arctic-type stations from the Greenland Sea and Fram Strait (1-way ANOSIM, global test $\mathrm{p}=0.001$, global $\mathrm{R}=0.419$ ), with all pairwise tests between groups being significant. Except for taxa present in all geographic groups, the following taxa contributed mostly to the similarities of zooplankton communities within the indicated hydrographical regions and were characteristic for them: Aglantha digitale and Oikopleura spp. for the eastern branch of WSC, Calanus glacialis and Echinodermata larvae for the shelf region, and C. hyperboreus for the Arctic-type and western branch.

\section{Influence of environmental variables}

Environmental variables explained $30.6 \%$ of the variation in species-environment relationships in the RDA model $(p=0.001)$. The most important predictors were station water depth and water temperature, explaining $13 \%$ and $9 \%$ of species variability, respectively (Table 3). Only satellite chlorophyll a concentration data from June were significant and explained $2 \%$ of zooplankton variability in addition to the other environmental variables. The gradient between the northern and southern part of the study area is clearly seen along the temperature eigenvector in the ordination plot, illustrating the relationship between zooplankton taxa abundances (ind. $\mathrm{m}^{-2}$ ) and environmental variables, as well as the latitudinal range based on GLM (Fig. 3). The RDA analysis revealed that higher abundances of Calanus fin- marchicus males, Aglantha digitale, Limacina retroversa, and Bryozoa larvae, which were recorded in the southern part of the WSC, corresponded with higher temperatures. The presence of C. hyperboreus, older copepodite stages of Pseudocalanus spp. and Themisto libellula was associated with deep stations in the Greenland Sea and Fram Strait, located in the north-western part of the study area, while Parasagitta elegans, Frittilaria borealis and the larvae of echinoderms and cirripedes preferred eastern shelf areas. The presence of nearly all stages of C. glacialis was highly correlated with increasing sea-ice concentrations along the Spitsbergen shelf in the north-eastern part of the study area.

\section{Spatial distribution and variation partitioning}

PCNM analysis resulted in 82 PCNM eigenfunctions with positive eigenvalues, of which 20 were significant according to the forward selection procedure in RDA. The significant eigenfunctions were equally distributed among the 82 PCNM functions, representing mesozooplankton spatial variation from broad to local scale. The RDA model $(p=0.001)$ based on these 20 significant PCNMs used as predictors allowed explanation of $27.2 \%$ of the mesozooplankton community variation.

As mentioned above, $27.2 \%$ of the variation of the community composition data was spatially structured and explained by the PCNM eigenfunctions, while $30.6 \%$ of the variation was explained by the environmental variables. However, after applying variation partitioning for RDA, these proportions changed to $18.1 \%$ of variation being explained by environmental factors alone, $14.7 \%$ by the spatial distribution alone, and $12.5 \%$ being common to both (Fig. 4 ). The results indicate that variation resulting from changes in water and sampling depth, temperature, salinity, chlorophyll $a$ and sea ice concentrations was more important for the WSC mesozooplankton community than that explained by the spatial distribution of sampling stations, in spite of the large geographic extent of the study area.

\section{Inter-annual zooplankton variability}

In 2001，2002 and 2004, the highest total abundances of almost all species were observed (Table 4), which was especially visible for the small copepods such as Oithona similis, O. atlantica, Triconia (=Oncaea) borealis and Copepoda nauplii. In terms 
Table 2. Taxa found in this study, with their minimum, median and maximum values for abundance and biomass (dry mass, DM) across all stations. Biomasses of taxa with large size variance have not been calculated. For holoplankton species the biogeographic origin is given

\begin{tabular}{|c|c|c|c|c|c|c|c|}
\hline \multirow{2}{*}{ Species } & \multirow{2}{*}{$\begin{array}{l}\text { Biogeographic } \\
\text { origin }\end{array}$} & \multicolumn{3}{|c|}{ Abundance (ind. $\mathrm{m}^{-2}$ ) } & \multicolumn{3}{|c|}{ Biomass (mg DM m²) } \\
\hline & & Min. & Median & Max. & Min. & Median & Max. \\
\hline Calanus finmarchicus & Boreal & 2131 & 12464 & 520100 & 0.4 & 1164.3 & 45016.4 \\
\hline Calanus glacialis & Arctic & 0 & 97 & 25285 & 0 & 36.3 & 5467.1 \\
\hline Calanus hyperboreus & Arctic & 0 & 130 & 11817 & 0 & 44.84 & 7882.5 \\
\hline Microcalanus spp. & Boreo-Arctic & 0 & 146 & 7209 & 0 & 1.0 & 50.5 \\
\hline Pseudocalanus spp. & Boreo-Arctic & 200 & 2641 & 104316 & 1.5 & 15.9 & 393.2 \\
\hline Metridia longa & Boreo-Arctic & 0 & 28 & 2440 & 0 & 3.7 & 495.5 \\
\hline Paraeuchaeta norvegica & Boreal & 0 & 20 & 370 & 0 & 0 & 74.0 \\
\hline Acartia longiremis & Boreo-Arctic & 0 & 0 & 773 & 0 & 0 & 11.1 \\
\hline Gaetanus tenuispinus & Ubiquitous & 0 & 0 & 24 & 0 & 0 & 0.07 \\
\hline Aetideidae & Boreo-Arctic & 0 & 0 & 4 & 0 & 0 & 0.04 \\
\hline Heterorhabdus norvegicus & Boreal & 0 & 0 & 32 & 0 & 0 & 6.4 \\
\hline Metridia lucens & Boreal & 0 & 0 & 182 & 0 & 0 & 0.57 \\
\hline Temora longicornis & Boreal & 0 & 0 & 4.0 & 0 & 0 & 0.01 \\
\hline Scolecithricella minor & Ubiquitous & 0 & 0 & 137 & 0 & 0 & 0.86 \\
\hline Microsetella norvegica & Ubiquitous & 0 & 510.0 & 3257 & 0 & 0 & 3.4 \\
\hline Harpacticoida indet. & & 0 & 0 & 61 & 0 & 0 & 0.35 \\
\hline Oithona atlantica & Boreal & 0 & 529 & 9600 & 0 & 3.6 & 65.9 \\
\hline Oithona similis & Ubiquitous & 1500 & 30717 & 245440 & 3.7 & 76.2 & 608.8 \\
\hline Triconia (=Oncaea) borealis & Boreo-Arctic & 0 & 781 & 93338 & 0 & 1.6 & 190.4 \\
\hline Copepoda nauplii & & 140 & 6747 & 256667 & 0.6 & 30.1 & 1143.4 \\
\hline Evadne nordmanni & Ubiquitous & 0 & 0 & 3567 & & & \\
\hline Ostracoda & & 0 & 3 & 195 & 0 & 0.2 & 12.9 \\
\hline Cirripedia nauplii & & 0 & 0 & 827 & 0 & 0 & 17.4 \\
\hline Cirripedia cypris & & 0 & 0 & 1663 & 0 & 0 & 34.9 \\
\hline Cirripedia Facetotecta nauplii & & 0 & 0 & 26 & & & \\
\hline Themisto abyssorum & Boreo-Arctic & 0 & 93 & 1005 & & & \\
\hline Themisto libellula & Arctic & 0 & 8 & 878 & & & \\
\hline Isopoda Bopyridae & & 0 & 0 & 67 & & & \\
\hline Isopoda & & 0 & 0 & 44 & & & \\
\hline Thysanoessa inermis & Boreo-Arctic & 0 & 0 & 364 & & & \\
\hline Thysanoessa longicaudata & Boreal & 0 & 0 & 616 & & & \\
\hline Thysanoessa raschii & Boreo-Arctic & 0 & 0 & 356 & & & \\
\hline Euphausiacea nauplii & & 0 & 0 & 1304 & & & \\
\hline Euphausiacea calyptopis & & 0 & 72 & 1745 & 0 & 49.8 & 1200.2 \\
\hline Euphausiacea furcilia & & 0 & 47 & 1900 & & & \\
\hline Eupagurus zoea & & 0 & 0 & 7 & & & \\
\hline Hyas sp. zoea & & 0 & 0 & 100 & & & \\
\hline Hyas sp. megalopa & & 0 & 0 & 8 & & & \\
\hline Pandalus borealis zoea & & 0 & 0 & 1 & & & \\
\hline Munida zoea & & 0 & 0 & 4 & & & \\
\hline Decapoda larvae & & 0 & 4.0 & 4.0 & & & \\
\hline Aglantha digitale & Boreo-Arctic & 0 & 42 & 19455 & 0 & 17.9 & 8242.6 \\
\hline Halopsis ocellata & Boreo-Arctic & 0 & 0 & 4.0 & & & \\
\hline Dimophyes arctica & Boreo-Arctic & 0 & 0 & 15 & & & \\
\hline Beroë cucumis & Ubiquitous & 0 & 0 & 224 & & & \\
\hline Mertensia ovum & Arctic & 0 & 0 & 96 & & & \\
\hline Ctenophora larvae & & 0 & 0 & 533 & & & \\
\hline Ctenophora indet. & & 0 & 0 & 257 & & & \\
\hline Tornaria larvae & & 0 & 19.0 & 60.0 & & & \\
\hline Clione limacina & Arctic & 0 & 0 & 133 & 0 & 0 & 1410.8 \\
\hline Limacina helicina & Arctic & 0 & 74 & 8800 & 0 & 13. 2 & 1578.3 \\
\hline Limacina retroversa & Boreal & 0 & 0 & 365 & 0 & 0 & 65.5 \\
\hline Gastropoda veliger & & 0 & 0 & 218 & & & \\
\hline Bivalvia veliger & & 0 & 67 & 9003 & & & \\
\hline Tomopteris helgolandica & Boreal & 0 & 0 & 8 & & & \\
\hline Polychaeta larvae & & 0 & 0 & 125 & & & \\
\hline Polychaeta indet. & & 0 & 0 & 490 & & & \\
\hline Echinodermata larvae & & 0 & 94 & 20805 & 0 & 0.1 & 20.8 \\
\hline Bryozoa larvae & & 0 & 0 & 438 & & & \\
\hline Eukrohnia hamata & Boreo-Arctic & 0 & 576 & 5504 & & & \\
\hline Parasagitta elegans & Arctic & 0 & 6 & 1416 & & & \\
\hline Fritillaria borealis & Boreal & 0 & 0 & 8600 & 0 & 0 & 4.8 \\
\hline Oikopleura spp. & Boreo-Arctic & 0 & 292 & 22886 & & & \\
\hline
\end{tabular}


of relative abundance, copepoda nauplii was the second most important taxa, after $O$. similis, in the first $2 \mathrm{yr}(8.5$ and $10.17 \%)$, while this role was overtaken by Calanus finmarchicus in the following years. In

Table 3. Conditional effects of explanatory environmental variables from the redundancy analysis (RDA). Lambda A values are the canonical eigenvalues with $F$ - and p-statistics obtained by means of permutation tests

\begin{tabular}{|lcrc|}
\hline Explanatory variables & Lambda A & $F$ & $\mathrm{p}$ \\
\hline Sea depth & 0.13 & 19.69 & 0.001 \\
Temperature & 0.09 & 17.13 & 0.001 \\
Sampling depth & 0.04 & 6.38 & 0.001 \\
Salinity & 0.02 & 3.63 & 0.001 \\
Sea-ice concentration & 0.01 & 2.86 & 0.001 \\
Chlorophyll a & 0.02 & 2.00 & 0.015 \\
\hline
\end{tabular}

fact, 2009 was the first year when the most abundant species was not the ubiquitous $O$. similis, comprising a proportion of around 10 to $11 \%$ of all taxa in the previous years, but the boreal $C$. finmarchicus, reaching a relative abundance of $12 \%$. In 2004, 2005 and 2006, boreal species, such as $O$. atlantica, were observed in relatively higher numbers. C. glacialis was observed in the WSC mainly in 2004 and 2009, while C. hyperboreus was found mostly in 2007 and 2008. Overall, the sum of these species-specific observations could suggest an increasing abundance of boreal taxa in the WSC and adjacent areas.

Supporting trends can be seen in relative abundances and biomasses of holoplankton (Fig. 5). Ubiquitous species were most abundant, with the exception of 2006 and 2009, with relative contributions ranging from $45.1 \%$ in 2004 to $65.9 \%$ in 2002. In

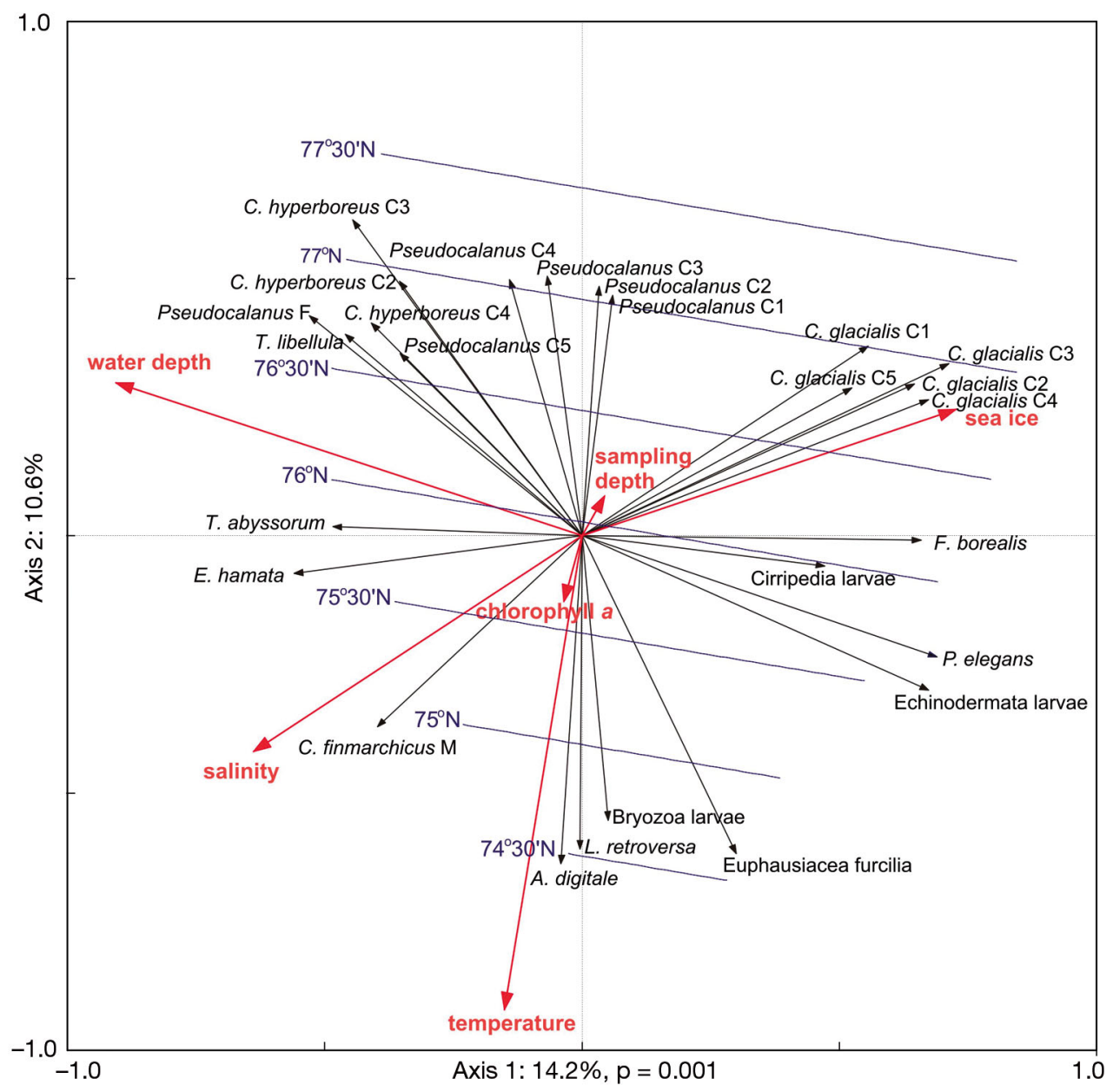

Fig. 3. Ordination plot from redundancy analysis (RDA) on mesozooplankton taxa abundances (black arrows) and their relation to environmental variables (red arrows). The 21 best fitted taxa are shown in the plot. Blue lines represent the parallels of latitude of the sampling sites. See Table 2 for species names 


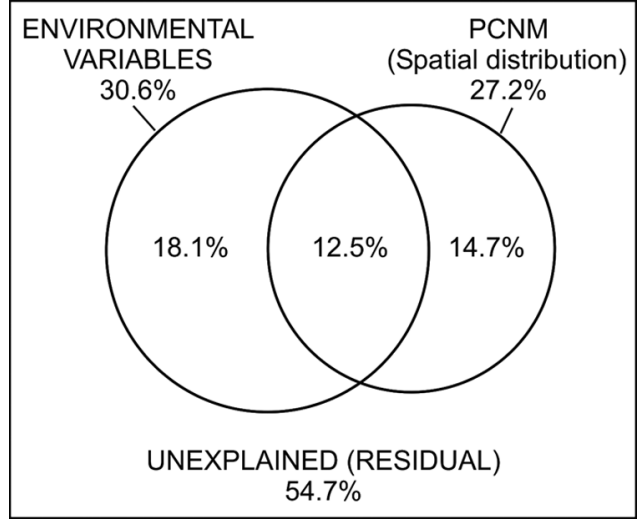

Fig. 4. Venn diagram representing the partition of the variation of zooplankton community composition between 2 sets of explanatory variables: environmental factors (left circle) and principal coordinates of neighbour matrices (PCNM) eigenfunctions representing spatial distribution (right circle).

The box represents $100 \%$ of the variation
2006 and 2009, the highest fractions of boreal species were observed (48.2\% and $45.2 \%$, respectively). Boreo-Arctic species were the second-most abundant group only in 2001 and 2002, whereas the group of boreal species became more dominant in 2003 to 2009. The shift towards increasing dominance of boreal taxa was even clearer in holoplankton biomass; the relative biomass of boreo-Arctic species was the highest only in 2001 and 2002, while boreal species gradually increased their relative proportion in the following years, reaching $84.3 \%$ of the zooplankton biomass in 2009.

Based on weighted Spearman's correlations of the abundances of species and their life stage composition at sampling stations between each pair of sampling years, the 2STAGE analysis revealed the presence of 2 groups with the computed correlations $\mathrm{r}^{2}>$ 0.6, illustrated by MDS plot (Fig. 6). The first group included 2001, 2003, 2004, 2006, 2007, and the sec-

Table 4. Results of similarity percentages (SIMPER) analysis: relative abundances of selected taxa which contributed most to the dissimilarities between years, and to the within-groups similarities, with a cut-off at $50 \%$. MEAN is the average total mesozooplankton abundance (ind. $\mathrm{m}^{-2}$ ) across stations in a given year

\begin{tabular}{|c|c|c|c|c|c|c|c|c|c|}
\hline Species & 2001 & 2002 & 2003 & 2004 & 2005 & 2006 & 2007 & 2008 & 2009 \\
\hline Oithona similis & 9.20 & 11.70 & 10.04 & 10.14 & 10.84 & 10.37 & 10.91 & 10.64 & 11.60 \\
\hline Copepoda nauplii & 8.50 & 10.17 & 8.47 & 8.61 & 8.35 & 8.12 & 8.71 & 8.65 & 9.98 \\
\hline Calanus finmarchicus & 7.63 & 9.82 & 9.46 & 9.29 & 10.44 & 9.45 & 10.36 & 9.66 & 11.99 \\
\hline Triconia borealis & 7.14 & 8.18 & 4.66 & 5.99 & 5.13 & 5.56 & & 6.54 & \\
\hline Pseudocalanus spp. & 7.08 & 8.33 & 6.98 & 7.90 & 7.80 & 7.41 & 8.11 & 8.56 & 8.85 \\
\hline Oikopleura spp. & 6.07 & & 4.43 & & & & & & \\
\hline Oithona atlantica & 5.78 & & & 6.17 & 4.59 & 5.54 & & & \\
\hline Aglantha digitale & & 4.85 & & & & & & & \\
\hline Eukrohnia hamata & & & 6.13 & 6.19 & 5.59 & 5.56 & 6.68 & 5.82 & 6.11 \\
\hline Calanus hyperboreus & & & & & & & 6.20 & 5.24 & \\
\hline Calanus glacialis & & & & & & & & & 5.13 \\
\hline MEAN & 2958 & 2170 & 1182 & 2454 & 1139 & 1547 & 1144 & 1175 & 1285 \\
\hline
\end{tabular}
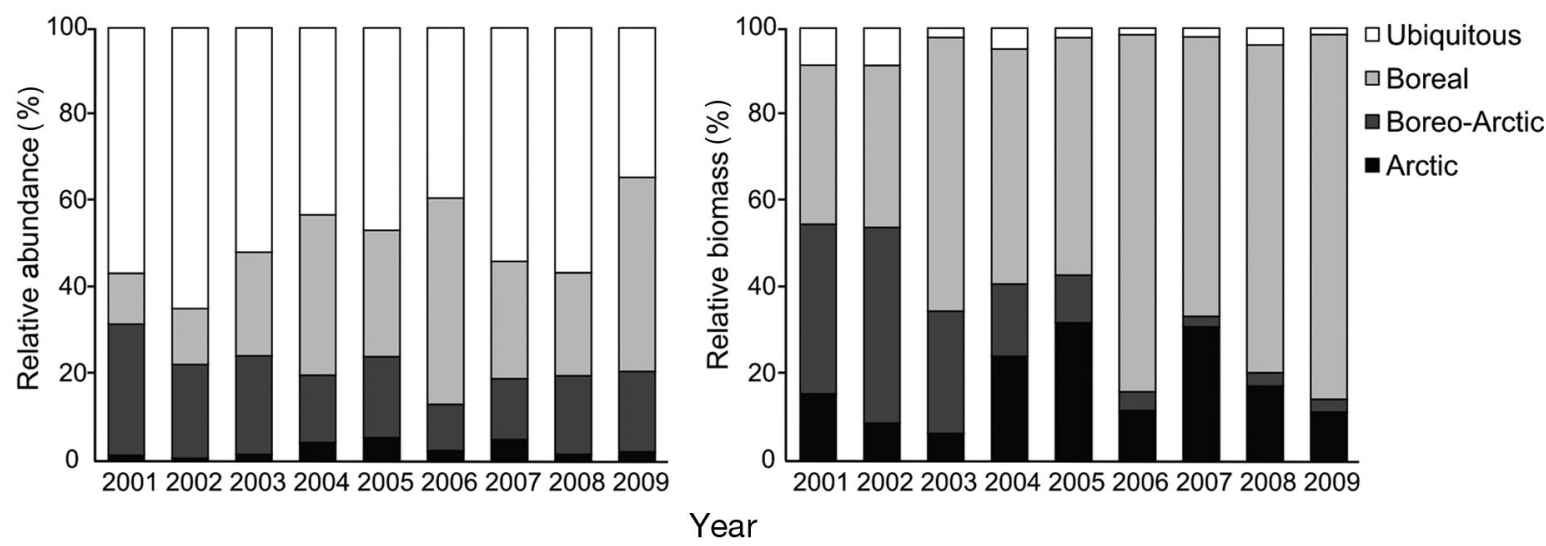

Fig. 5. Changes in relative abundances and biomasses of holoplankton species groups over the study period 


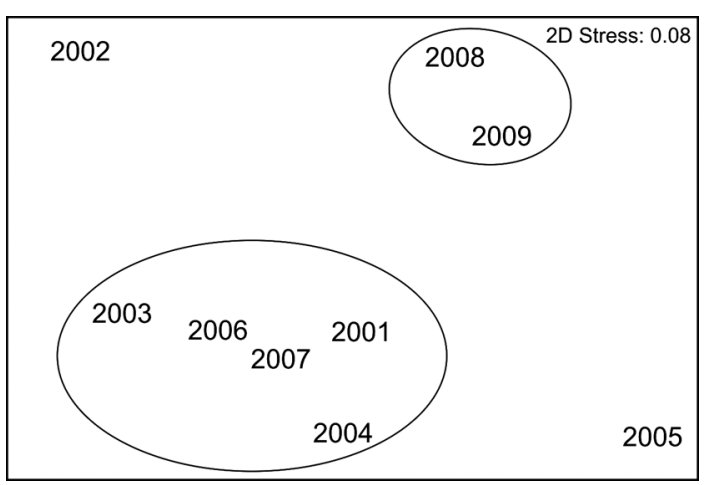

Fig. 6. MDS plot showing differences between years, derived from 2STAGE analysis computed for patterns in abundances of taxa (ind. $\mathrm{m}^{-2}$ ) among stations

ond one consisted of 2008 and 2009, while 2002 and 2005 were defined as outliers (Fig. 6).

\section{DISCUSSION}

\section{Zooplankton spatial distribution}

The mesozooplankton community in the study area, including the WSC, shelf areas of Spitsbergen and the Barents Sea, and the Greenland Sea with the Fram Strait, was a mixture of boreal, boreo-Arctic, Arctic and ubiquitous species, with large spatial and interannual variations. The main environmental factors driving zooplankton variability were temperature and water depth at stations, despite the fact that sampling only took place in the upper part of the water column. The role of these variables in explaining zooplankton variability can be attributed to the species' biology, as discussed below. The WSC transports great amounts of heat northwards (Piechura \& Walczowski 2009); therefore, the area of the southern stations is ice free during most of the year (Svendsen et al. 2002), and was characterised mainly by the presence of boreal species, such as Aglantha digitale, Limacina retroversa or Calanus finmarchicus. The stations in the eastern part of the study area, on the Spitsbergen shelf, which were located in the flow of fresher and colder Arctic waters associated with the coastal South Cape Current, had an increasing number of C. glacialis and meroplanktonic Echinodermata larvae. C. glacialis is a cold-water Arctic shelf species, predominating the Calanus stock in the northern Barents Sea (Tande 1991). The species' predominance in the Arctic may be related to its use of ice algae as an important food source, especially by females during spawning (Tourangeau \& Runge 1991, Søreide et al. 2010, Weydmann et al. 2013). This could explain the positive relation between $C$. glacialis abundance and sea ice concentrations in our analyses. The stations in the north-western part of the study area, where the water masses of the WSC mix with fresher and colder waters originating from the Greenland Sea (Boreal Basin Gyre) or the Fram Strait (Loeng \& Drinkwater 2007, Oliver et al. 2008), had increasing water depth and, consequently, characteristic species at these stations, Calanus hyperboreus and Themisto libellula, are typically associated with deep waters of the Greenland Sea (Hirche 1997), supporting the relationships found in our analyses.

PCNM is a powerful tool for analysing the spatial variation in species composition, although so far it has been mostly used in terrestrial ecology (Borcard \& Legendre 2002, Legendre et al. 2009). This study demonstrated that it can be successfully applied to ocean studies as well. The PCNM results showed that the zooplankton community exhibits large spatial variations in the study area, from local to broad scale. Apart from the differences between the sampling years, the small scale variation could be ascribed to the mesoscale features observed within the WSC and in the frontal zones between Atlantic and Arctic-type waters. Mesoscale physical dynamics are known to govern the major time and spatial scales of biological variability in terms of biomass, production and export, and they seem to have a strong impact on ecosystem structure and functioning, although observational evidence in the NE Atlantic is still rather limited (Garcon et al. 2001, Yebra et al. 2009). The large scale variation was connected to the huge geographic range of our sampling stations, especially its latitudinal extent.

Ecologists use variation partitioning in order to understand the contribution of the environment, independent of spatial distribution, and vice versa, as well as to control for inflated type I error in assessing the environmental component under spatial autocorrelation (Legendre et al. 2009, Peres-Neto \& Legendre 2010). In this study, this method allowed us to determine that variation in zooplankton explained by environmental factors was higher than that explained by the spatial distribution of sampling stations, in spite of the large geographic extent of the study area. However, some variation remained that could not be partitioned and was explained by both factors together, most likely due to a correlation between them. For example, water temperature and 
salinity decrease as the WSC penetrates northwards, as a result of water transformation (Piechura \& Walczowski 2009), resulting in a correlation between environmental variables and spatial distribution of stations. The analytical tools used in the study explained most of the linear, explainable variation, and the remaining unexplained variance was most likely associated with sampling and the large spatial-temporal heterogeneity of the mesozooplankton community in the water column or stochastic processes such as dispersal, establishment and mortality, or noise (ter Braak 1994).

\section{Zooplankton inter-annual variability}

The zooplankton community inhabiting the WSC displayed significant year-to-year variability, with a gradual transition from dominance of ubiquitous and boreo-Arctic species towards an increasing contribution of boreal ones, rather than an abrupt regime shift or tipping point as described by Carstensen \& Weydmann (2012). Parallel to the changes observed in zooplankton, positive trends in temperature and salinity of the AW were observed in 2000 to 2009, based on measurements conducted at the same time as the zooplankton sampling (Walczowski et al. 2012), whereas June to July sea ice extent in the study area and the spring bloom varied substantially between 2001 and 2009 (Acker \& Leptoukh 2007, Fetterer et al. 2002, updated 2009).

The beginning of the zooplankton sampling period coincided with small changes in the mean temperature of the AW layer during the summers of 2001 and 2002 (Piechura \& Walczowski 2009) and wide open waters found in the Fram Strait, especially in 2001 (Fetterer et al. 2002, updated 2009). The spring bloom began in the Eastern Shelf in May in these years, spread towards western stations in June and finished by the end of sampling period in July (Acker \& Leptoukh 2007). During these years the zooplankton was characterised by high abundances of almost all taxa, but small copepods such as the ubiquitous Oithona similis and boreo-Arctic Triconia borealis declined after 2002. Similar observations of regime changes were made in the Gulf of Maine by Pershing et al. (2005), who described a common pattern of interdecadal variability for a number of taxa including Oithona spp. and Pseudocalanus spp., and noted a dramatic increase in these taxa around 1990, followed by a rapid decline in 2002 driven by largescale changes in the salinity of the Northwest Atlantic Shelf.
In contrast, 2003 was considered a cold year by Walczowski et al. (2012), the marginal ice zone appeared close to the north-western part of the study area (Fetterer et al. 2002, updated 2009) and the spring bloom did not coincide with zooplankton sampling apart from at the southernmost stations. Heavy ice conditions around the southern part of Spitsbergen in 2004 (Fetterer et al. 2002, updated 2009) and advection of the Arctic waters from shelf areas of the Barents Sea into the eastern branch of the WSC caused both the delay in spring bloom in this area and peak abundances of Arctic species such as Calanus glacialis and Clione limacina, as well as larval stages of benthic echinoderms, where these taxa were usually marginal.

Between 2004 and 2006, significant increases in AW temperature and salinity were observed, together with the northward shift of warm water resulting in the highest AW salinity in 2005 and the highest AW temperature recorded in summer 2006. The northward advance of AW in 2006 was an unprecedented event: the position of the warm-water tongue shifted more than $350 \mathrm{~km}$ to the north, and temperatures in the WSC reached the highest values ever recorded (Walczowski et al. 2012). Also, the spring bloom lasted longer compared to other sampling years. The increased occurrence of Oithona atlantica, especially pronounced in 2006, indicates an increased contribution of Atlantic fauna to the zooplankton community in the WSC area.

After 2006, the AW temperature and salinity decreased rapidly and peaked again in 2009 (Walczowski et al. 2012). In 2008 and 2009, the spring bloom coincided with the sampling time apart from at the eastern shelf stations (Acker \& Leptoukh 2007). The increasing proportions of boreal species over the study period and the shift to their dominance in 2009 were mainly due to high counts of Calanus finmarchicus. This observation is consistent with the findings of Reygondeau \& Beaugrand (2011) which suggested that $C$. finmarchicus would increase its abundance at the northern edge of its spatial distribution.

This data set is too short to assess if the observed increasing dominance of boreal species in the WSC and adjacent areas is just a temporary phenomenon or constitutes a more persistent trend. The higher proportion of boreal species could have been a result of stronger advection of AW northwards, like in 2006, although the following years did not show any extreme hydrographical properties (Walczowski et al. 2012). Alternatively, the high proportion of boreal species in recent years could be part of an inter- 
decadal oscillating behaviour, similar to what was observed in the Gulf of Maine (Pershing et al. 2005). However, the hydrographical data from the WSC, which were collected simultaneously with the presented zooplankton data and in the years before zooplankton sampling started, indicate positive trends in summer AW salinity and temperature over the last $15 \mathrm{yr}$ (Walczowski et al. 2012), which could suggest that this trend is indeed persistent.

Rising water temperature results in increasing marine copepod metabolic processes such as respiration and oxygen consumption (Hirche 1987, Ikeda et al. 2001). Temperature also affects the growth of Atlantic and Arctic zooplankton directly through regulation of development time and final weight (Huntley \& Lopez 1992), and development rates (Møller et al. 2012), or indirectly by influencing relationships among species including primary producers, as well as zooplankton consumers or competitors (Kirby \& Beaugrand 2009), which in turn affect the distribution of zooplankton development stages and community composition ( $\mathrm{Ji}$ et al. 2012). The above processes may lead to ecological regime shifts such as the climate-induced regime shift in the North Atlantic and the high Arctic that occurred in the 1920s and 1930s and involved changes in cod and capelin distribution and a northward expansion of boreal invertebrates (Drinkwater 2006) or a dramatic shift from benthic fish to a pelagic fish/macroinvertebrate-dominated system in the Northwest Atlantic in the late 1980s and early 1990s (Frank et al. 2005).

The observed trend in the increasing numbers of boreal copepods at the gateway to the Arctic is consistent with strong biogeographic shifts in all copepod assemblages and the northward extension of warm-water species by more than $10^{\circ}$ latitude, associated with a decrease in the number of colder-water species, described in the eastern North Atlantic and European shelf seas (Beaugrand et al. 2002). The shifts in geographic ranges may mean more possibilities for hybridisation between Arctic and Atlantic species, as observed for Calanus finmarchicus and $C$. glacialis by Parent et al. (2012) in the Arctic and Northwest Atlantic. The 'warmer Arctic' scenarios also forecast a switch in the Arctic marine food web from large, lipid-rich Arctic herbivores to boreal grazers, which could mean that primary production will be utilised by smaller, faster-growing and less lipid-rich species (Søreide et al. 2010) and consequently, the food resources available to the top Arctic predators such as seabirds, seals, and whales would be reduced (Weslawski et al. 2009).
Acknowledgements. This research was supported by the Arctic Tipping Points project (www.eu-atp.org), contract number 226248 of the Framework Program 7 of the European Union. We thank M. Głuchowska from the Institute of Oceanology, Polish Academy of Sciences (IO PAN) for her assistance in assigning species to biogeographic ranges and J. Rodrigues from the University of Cambridge for providing sea ice concentration data. Analyses of chlorophyll a used in this paper were produced with the Giovanni online data system, developed and maintained by the NASA Goddard Earth Sciences, Data and Information Services Center (GES DISC).

\section{LITERATURE CITED}

Acker JG, Leptoukh G (2007) Online analysis enhances use of NASA Earth science data. EOS Trans AGU 88:14-17

Beare DJ, McKenzie E (1999) Connecting ecological and physical time-series: the potential role of changing seasonality. Mar Ecol Prog Ser 178:307-309

Beaugrand G, Reid PC, Ibanez F, Lindley JA, Edwards M (2002) Reorganization of North Atlantic marine copepod biodiversity and climate. Science 296:1692-1694

Błachowiak-Samołyk K, Søreide JE, Kwasniewski S, Sundfjord A, Hop H, Falk-Petersen S, Hegseth EN (2008) Hydrodynamic control of mesozooplankton abundance and biomass in northern Svalbard waters $\left(79-81^{\circ} \mathrm{N}\right)$. Deep-Sea Res II 55:2210-2224

Borcard D, Legendre P (2002) All-scale spatial analysis of ecological data by means of principal coordinates of neighbour matrices. Ecol Model 153:51-68

Carstensen J, Weydmann A (2012) Tipping points in the Arctic: eyeballing or statistical significance? Ambio 41: $34-43$

Carstensen J, Weydmann A, Olszewska A, Kwasniewski S (2012) Effects of environmental conditions on the biomass of Calanus spp. in the Nordic Seas. J Plankton Res 34:951-966

Clarke KR, Somerfield PJ, Airoldi L, Warwick RM (2006) Exploring interactions by second-stage community analyses. J Exp Mar Biol Ecol 338:179-192

Corkett CJ, McLaren IA (1979) The biology of Pseudocalanus. Adv Mar Biol 15:1-231

deYoung B, Harris R, Alheit J, Beaugrand G, Mantua N, Shannon L (2004) Detecting regime shifts in the ocean: data considerations. Prog Oceanogr 60:143-164

- Drinkwater KF (2006) The regime shift of the 1920s and 1930s in the North Atlantic. Prog Oceanogr 68:134-151

Fetterer F, Knowles K, Meier W, Savoie M (2002, updated 2009) Sea Ice Index. National Snow and Ice Data Center, Boulder, CO. Digital media

Frank KT, Petrie B, Choi JS, Leggett WC (2005) Trophic cascades in a formerly cod-dominated ecosystem. Science 308:1621-1623

> Garcon WC, Oschlies A, Doney SC, McGillicuddy D, Waniek J (2001) The role of mesoscale variability on plankton dynamics in the North Atlantic. Deep-Sea Res II 48:2199-2226

Hays GC, Richardson AJ, Robinson C (2005) Climate change and marine plankton. Trends Ecol Evol 20: 337-344

Hirche HJ (1987) Temperature and plankton II. Effect on respiration and swimming activity in copepods from the Greenland Sea. Mar Biol 94:347-356

> Hirche HJ (1997) Life cycle of the copepod Calanus hyper- 
boreus in the Greenland Sea. Mar Biol 128:607-618

Hughes L (2000) Biological consequences of global warming: is the signal already apparent? Trends Ecol Evol 15: 56-61

> Huntley ME, Lopez MDG (1992) Temperature-dependent production of marine copepods: a global synthesis. Am Nat 140:201-242

Ikeda T, Kanno Y, Ozaki K, Shinada A (2001) Metabolic rates of epipelagic marine copepods as a function of body mass and temperature. Mar Biol 139:587-596

IPCC (Intergovernmental Panel on Climate Change) (2007) Climate change 2007. The physical science basis. Contribution of Working Group I to the Fourth Assessment Report of the IPCC. Cambridge University Press, Cambridge

Jaschnov WA (1970) Distribution of Calanus species in the seas of the Northern Hemisphere. Int Rev Gesamten Hydrobiol 55:197-212

> Ji R, Ashjian CJ, Campbell RG, Chen C and 4 others (2012) Life history and biogeography of Calanus copepods in the Arctic Ocean: an individual-based modelling study. Prog Oceanogr 96:40-56

Kirby RR, Beaugrand G (2009) Trophic amplification of climate warming. Proc R Soc Lond B Biol Sci 276:4095-4103

> Kosobokova KN, Hopcroft RR, Hirche HJ (2011) Patterns of zooplankton diversity through the depths of the Arctic's central basins. Mar Biodiversity 41:29-50

> Kwasniewski S, Gluchowska M, Walkusz W, Karnovsky NJ, and 9 others (2012) Inter-annual changes in zooplankton on the West Spitsbergen Shelf in relation to hydrography, and their consequences for the diet of planktivorous seabirds. ICES J Mar Sci 69:890-901

> Legendre P, Mi X, Ren H, Ma K, Yu M, Sun IF, He F (2009) Partitioning beta diversity in a subtropical broadleaved forest of China. Ecology 90:663-674

Leps J, Smilauer P (2003) Multivariate analysis of ecological data using CANOCO. Cambridge University Press, Cambridge

Lindley JA (1977) Continuous plankton records: the distribution of the Euphausiacea (Crustacea: Malacostraca) in the north Atlantic and the North Sea 1966-1967. J Biogeogr 4:121-133

Loeng H, Drinkwater K (2007) An overview of the ecosystems of the Barents and Norwegian Seas and their response to climate variability. Deep-Sea Res II 54: 2478-2500

Møller EF, Maar M, Jónasdóttir SH, Nielsen TG, Tönnesson $\mathrm{K}$ (2012) The effect of changes in temperature and food on the development of Calanus finmarchicus and Calanus helgolandicus populations. Limnol Oceanogr 57:211-220

- Mumm N, Auel H, Hanssen H, Hagen W, Richter C, Hirche HJ (1998) Breaking the ice: large-scale distribution of mesozooplankton after a decade of Arctic and transpolar cruises. Polar Biol 20:189-197

> Oliver KIC, Eldevik T, Stevens DP, Watson AJ (2008) A Greenland Sea perspective on the dynamics of postconvective eddies. J Phys Oceanogr 38:2755-2771

Parent GJ, Plourde S, Turgeon J (2012) Natural hybridization between Calanus finmarchicus and C. glacialis (Copepoda) in the Arctic and Northwest Atlantic. Limnol

Editorial responsibility: Anna Pasternak,

Moscow, Russian Federation
Oceanogr 57:1057-1066

> Park T (1994) Geographic distribution of the bathypelagic genus Paraeuchaeta (Copepoda, Calanoida). Hydrobiologia 292-293:317-332

> Peres-Neto PR, Legendre P (2010) Estimating and controlling for spatial structure in the study of ecological communities. Glob Ecol Biogeogr 19:174-184

> Pershing AJ, Greene CH, Jossi JW, O'Brien L, Brodziak JKT, Bailey BA (2005) Interdecadal variability in the Gulf of Maine zooplankton community, with potential impacts on fish recruitment. ICES J Mar Sci 62:1511-1523

> Piechura J, Walczowski W (2009) Warming of the West Spitsbergen Current and sea ice north of Svalbard. Oceanologia 51:147-164

Razouls C, de Bovée F, Kouwenberg J, Desreumaux N (2005-2012) Diversity and geographic distribution of marine planktonic copepods. Available at copepodes. obs-banyuls.fr/en

Reygondeau G, Beaugrand G (2011) Future climate-driven shifts in distribution of Calanus finmarchicus. Glob Change Biol 17:756-766

Søreide JE, Leu E, Berge J, Graeve M, Falk-Petersen S (2010) Timing of blooms, algal food quality and Calanus glacialis reproduction and growth in a changing Arctic. Glob Change Biol 16:3154-3163

Spielhagen RF, Werner K, Sorensen SA, Zamelczyk K, and 5 others (2011) Enhanced modern heat transfer to the Arctic by warm Atlantic water. Science 331:450-453

Stroeve J, Holland MM, Meier W, Scambos T, Serreze M (2007) Arctic sea ice decline: faster than forecast. Geophys Res Lett 34:L09501, doi:10.1029/2007GL029703

> Svendsen H, Beszczy ska-Moller A, Hagen JO, Lefauconnier B, and 11 others (2002) The physical environment of Kongsfjorden-Krossfjorden, an Arctic fjord system in Svalbard. Polar Res 21:133-166

Tande KS (1991) Calanus in North Norwegian fjords and in the Barents Sea. Polar Res 10:389-407

ter Braak CJF (1994) Canonical community ordination. Part I: Basic theory and linear methods. Ecoscience 1:127-140

Tourangeau S, Runge JA (1991) Reproduction of Calanus glacialis under ice in spring in southeastern Hudson Bay, Canada. Mar Biol 108:227-233

- Walczowski W, Piechura J, Goszczko I, Wieczorek P (2012) Changes in Atlantic water properties: an important factor of the European Arctic marine climate. ICES J Mar Sci 69:864-869

Weslawski JM, Kwasniewski S, Stempniewicz L (2009) Warming in the Arctic may result in the negative effects of increased biodiversity. Polarforschung 78:105-108

> Weydmann A, Kwasniewski S (2008) Distribution of Calanus populations in a glaciated fjord in the Arctic (Hornsund, Spitsbergen)-an interplay between biological and physical factors. Polar Biol 31:1023-1035

Weydmann A, Søreide JE, Kwaśniewski S, Leu E, FalkPetersen S, Berge J (2013) Ice-related seasonality in zooplankton community composition in a high Arctic fjord. J Plankton Res 35:831-842

> Yebra L, Harris R, Head EJH, Yashayaev I, Harris LR, Hirst AG (2009) Mesoscale physical variability affects zooplankton production in the Labrador Sea. Deep-Sea Res I 56:703-715

Submitted: April 9, 2013; Accepted: December 12, 2013

Proofs received from author(s): March 6, 2014 